ACTA UNIVERSITATIS WRATISLAVIENSIS No 3985

Slavica Wratislaviensia CLXXII • Wrocław 2020

https://doi.org/10.19195/0137-1150.172.1

Data przesłania artykułu: 16.09 .2019

Data akceptacji artykułu: 5.10.2019

\author{
OLGA DEMIDOVA
}

Leningradzki Uniwersytet Państwowy im. A. Puszkina, Rosja

\title{
Столица и провинция: эмигрантский вариант
}

\section{Часть 1. Оппозиция „столица-провинция” в истории культуры. Русский Берлин}

Отношения столицы и провинции в основе своей суть отношения статусные, иерархические, т. е. отношения власти и подчинения. Эта иерархичность складывалась исторически и в свернутом виде закрепилась в самих терминах: во всех европейских языках семантическим ядром слова столица (англ. capital, франц. capitale, исп. capital, нем. Hauptstadt) является значение главенства. Столицей назывался главный (головной) и в этом смысле единственный город страны; нередко им становилось первое поселение, из которого со временем вырастал город, исходно сосредоточивавший в себе все основные столичные функции: государственно-административную, политическую, экономическую, культурную и пр. Русское слово „столица” восходит к слову „стол” в устаревшем значении „престол” и также является именованием главного и поначалу единственного города княжества.

Термин „провинция”, к которому восходят одноименные термины в современных романских, германских, славянских языках (фр. province, исп. province, англ. province, нем. Provinz, польск. prowincja и мн. др.) берет свое начало от латинского „provincia”", обозначавшего подвластные Риму территории вне Апеннинского полуострова и управлявшиеся римскими наместниками, то есть территории иностранные, находившиеся на других землях и в силу этого другие, чуждые и враждебные, требовавшие постоянного над-

${ }^{1}$ Pro- - от имени кого-либо, vincere - побеждать, управлять; т. е. территории, управляемые от имени Рима. 
зора и жесткого контроля. Как известно, Римская империя подразделялась на собственно Рим и его провинции, занимавшие по отношению к первому подчиненное положение. Первой римской провинцией была территория нынешнего французского Прованса, что и определило значение слова provincial и фразы en province (за пределами Парижа) в современном французском языке. В русский язык термин „провинция” вошел в XVII в. из польского и окончательно закрепился в XVIII в. как повторное заимствование из немецкого.

Так географическая экстерриториальность обусловила принцип и специфику административного устройства, основанного на жесткой иерархии и сохранившегося до Нового и Новейшего времени: провинциями Британской империи назывались северо-американские колонии до обретения ими независимости; провинции были единицей административно-территориального деления Российской империи с 1719 по 1755 гг. и Франции до Великой французской революции; деление на провинции остается актуальным в современной Канаде, состоящей из десяти провинций и трех территорий. Эти же причины обусловили семантику слова и семиотику понятия: провинция традиционно понимается как не-столица, как нечто подчиненное ей и зависящее от нее, как территория с более низким административным, геополитическим, культурным статусом.

Векторы отношений столицы и провинции обоюдно направлены друг к другу и в точке соприкосновения нацелены на взаимоотрицание: столица стремится подчинить себе провинцию, законодательно закрепить и сохранить ее подчиненное положение; провинция, в свою очередь, стремится избавиться от состояния зависимости, преодолеть подчиненность, доказать собственную значимость и независимость от столицы. Таким образом, самоидентификация и самореализация каждой из составляющих этой сложившейся в культуре сущностной оппозиции в негативном режиме основывается на своем „другом” и отталкивается от него: отрицая независимость провинции, столица реализует собственную самодостаточность и ведущую роль в культуре, тогда как провинция пытается обрести свою значимость и высокий культурный статус, отрицая зависимость от столицы и подчиненность ей.

В связи с этим необходимо разделить (развести) два понятия: провинциальность и провинциализм. Оба представляют собой утверждение через отрицание в рамках оппозиции „столица-провинция”, однако механизм и сущность этого процесса различны. Провинциальность есть понятие сугубо территориальное, указывающее на место рождения и/или проживания. Провинциал в указанном понимании - это тот, кто живет в провинции, он не столичный житель, он „другой”, однако его „друговость” и его самоидентификация держатся не на сопоставлении со столицей, а на утверждении собственной идентичности и обусловленной ею значимости, исходя из них самих. Провинциализм же есть состояние сознания: в этом случае самоиден- 
тификация основана на противопоставлении себя столичному жителю в режиме „я не хуже”, т. е., по существу, „я” определяется через „другого”, пусть и в негативном режиме ${ }^{2}$. Очевидно, что можно жить в столице и при этом оставаться дремучим провинциалом, равно как, не уезжая из провинции, сделаться вполне „столичным жителем” в духовном и культурном смысле, поскольку критерий самоопределения и оценки в данном случае не географический, а аксиологический.

При всей исходной иерархичности оппозиции „столица-провинция” она далеко не статична — напротив, отношения между ее составляющими носят динамический характер, не сводясь к модусу господства и подчинения. Представляется возможным говорить об исторически сложившейся типологии отношений, включающей, как минимум, четыре варианта: подчиненности, диалога, копирования и противостояния, обусловившей те изменения в рамках указанной оппозиции, о которых пойдет речь ниже.

В истории многих государств в определенный момент развития в силу причин различного рода - геополитических, климатических, экономических - происходила смена столиц, в результате чего складывалась новая культурная оппозиция: старой и новой столицы ${ }^{3}$. При этом обе столицы имели высокий статус, хотя и основанный на различных факторах: старая столица выступала как укоренившийся в историческом сознании народа национальный символ и хранительница традиционных историко-культурных ценностей, на которых держались завоеванные в прошлом мощь и слава государства; новая символизировала его настоящее и проецировала будущее.

2 Ср. предложенную М. В. Строгановым сопоставительную трактовку этих феноменов: „Провинциализм - это одно из воплощений социальной иерархии, организованное (в отличие от других - сословных, возрастных) не по „вертикали”, но по „горизонтали”, в пространстве. Провинциализм осознается самим носителем, который стремится компенсировать свою социальную неполноценность перед представителями высших социальных ступеней. Провинциальность - это неотрефлектированное самим носителем отставание в моде, манере поведения и т. д., которое может быть легко преодолено при освоении этим человеком современного уровня культуры”, А. Ю. Сорочан, М. В. Строганов, Провинииальный текст в русской художественной культуре, „Russian Studies. Ежегодник русской филологии и культуры” 2000, т. 3, № 2, с. 447-453 (статья представляет собой реферативный обзор докладов, прочитанных на 2-й международной научной конференции „Провинциальный текст в русской художественной культуре" в 2000 г. в Тверском государственном университете). См. также сборник материалов конференции: Русская провинция: миф-текст-реальность, сост. А. Ф. Белоусов, Т. В. Цивьян, ред. В. Н. Сажин, Москва-Санкт-Петербург 2000.

3 См. напр.: Каунас (с 1919) - Вильнюс (с 1940), Тирасполь (с 1929) - Кишинев (с 1940), Харьков (с 1919) - Киев (с 1934), Константинополь (с 330, как новая столица Римской империи, до захвата османами) - Стамбул (с 1453) - Анкара (с 1923), Москва (с 15 в.) - Санкт-Петербург (с 1713) - Москва (с 1727) - Санкт-Петербург (с 1730/32) - Москва (с 1918), Киото (с 794) - Эдо (Токио) (с 1868), Калькутта (с 1773) - Дели (с 1912), Филадельфия (с 1790) - Вашингтон (с 1800), Краков (с 11 в.) - Варшава (с 16 в.), Монреаль (с 1844) - Оттава (с 1858) и мн. столицы государств Азии и Африки, освободившихся от колониальной зависимости во второй половине XX в. 
Иными словами, первая осуществляла функцию культурной памяти, вторая способствовала реализации заложенного в культуре динамического потенциала ${ }^{4}$.

Однако с течением времени в связи со спецификой развития той или иной страны могли сложиться причины и возможности для явления, которое позволительно назвать культурной дивергенцией: столица словно делегировала часть своих функциональных „полномочий” одному из городов, опередивших ее в развитии в той или иной области и тем самым обретших сопоставимый со столичным статус. В этом случае в национальной культуре начинается период сосуществования двух или более столиц, причем первая остается в культуре как „просто столица”, т. е., главная столица, а остальные обретают расширительное „имя”, эксплицирующее область и уточняющее специфику их „столичности”: культурная столица, деловая столица, театральная столица, научная столица и мн. пр. Очевидно, что статус главной столицы достаточно высок и укоренен в традиции, в силу чего она не нуждается в подобном расширенном поименовании 5 .

Прежде чем перейти к специфике отношений столицы и провинции в русской эмиграции первой волны, необходимо отметить уникальность сложившегося в результате исхода из России после октября 1917 г. государства, получившего название зарубежной России, — государства „поверх границ”, не имевшего ни собственной территории, ни собственного правительства, ни системы административного деления, ни собственных финансов, но при этом последовательно сменившего три столицы.

Первой из них стал Берлин - признанная столица зарубежной России в первый период эмиграции (1918-1923). В силу разного рода геополитических, экономических и культурных причин ${ }^{6}$ к началу 1920-х гг. русскоязычное население Германии составляло около миллиона с четвертью человек (ср.: до Первой мировой войны оно, по разным сведениям, колебалось в пределах от восемнадцати до двадцати тысяч); примерно треть его жила

4 Ср., напр., противопоставление уходящей корнями в российское прошлое „порфироносной вдовы” - Москвы и новой столицы империи - Санкт-Петербурга в Медном всаднике Александра Пушкина.

5 Другой вариант этого культурного явления - присвоение, „приписывание”, по принципу культурной аналогии имени и статуса известной в международном масштабе столицы одному из городов иностранного государства, в результате также получающему международный статус, напр., восприятие Шанхая как дальневосточного Парижа (У. Герхарди, Полиглоmbl, Екатеринбург-Москва 2017, с. 330-340).

6 Карл Шлёгель указывает две из них как основные: вызванную послевоенным экономическим кризисом в Германии гиперинфляцию и развитую систему социального обеспечения, которой могли пользоваться и эмигранты (К. Шлёгель, Берлин, Восточный вокзал. Русская эмиграчия в Германии между двумя войнами (1918-1945), Москва 2004, с. 169); однако существенную роль сыграли и давние культурные связи двух стран, и установившиеся между Германией и советской Россией дружественные отношения, и близость Берлина по сравнению с другими западно-европейскими столицами.

Slavica Wratislaviensia 172, 2020

(C) for this edition by CNS 
в „русском” Берлине. Столь существенное увеличение численности русского населения города вызвало к жизни немало вошедших в копилку эмигрантской культурной памяти курьезов: например, „в одной из центральных газет появилась карикатура - улица германской столицы, пестрящая русскими вывесками ресторанов и магазинов с редкими вкраплениями: «Здесь говорят по-немецки»"7. Среди берлинских русских бытовал основанный на жизненных реалиях анекдот о том, как один из них, к своему несказанному удивлению, неожиданно встретил на улице „настоящего немца”. Художник Симон Сегал в своих воспоминаниях назвал это „русское засилье” „мирным завоеванием”, отметив, что „немцы об этом не беспокоились, они к этому уже привыкли"в.

В 1921 г. издательство Зиновия Гржебина выпустило путеводитель по русскому Берлину, в котором упоминались шесть банков, три ежедневные газеты, двадцать книжных лавок, конторы семнадцати крупных издательств и множество русских ресторанов, магазинов, организаций, разнообразных объединений и частных лиц, оказывающих различного рода услуги, от портновского дела до юридических консультаций 9 . А по сведениям Марка Раева, в Берлине в эти годы существовало сто восемьдесят восемь русских издательств, выпускавших художественную, научную, популярную, общественно-политическую литературу, книги для детей и учебники ${ }^{10}$. В целом количество издававшихся в Берлине книг по разным данным составляло от 2100 до 2200 наименований и превышало издательскую продукцию Москвы и Петербурга, вместе взятых ${ }^{11}$.

С точки зрения историко-культурной, именно это определило одну из специфических берлинских характеристик: до 1923 г. Берлин был прежде всего центром русскоязычного издательского дела. Другой его специфической чертой являлось то, что многие русские рассматривали Берлин либо как своего рода „перевалочный пункт” на дальнейшем пути в Европу, либо как место, где можно переждать период большевистской власти, которую до середины десятилетия многие считали временной и ждали ее падения, „не распаковывая чемоданов” и твердо намереваясь вернуться в освобож-

${ }^{7}$ Ю. А. Азаров, Диалог поверх барьеров. Литературная жизнь русского зарубежья: иентры эмиграчии, периодические издания, взаимосвязи (1918-1940), Москва 2005, с. 117.

8 Ibidem, c. 118. Подробнее о Сегале см. О. Л. Лейкинд, К. В. Махров, Д. Я. Северюхин, Художники Русского Зарубежья 1917-1939. Биографический словарь, Санкт-Петербург 1999, c. $518-519$.

9 Полный список см. К. Шлёгель, Берлин, Восточный вокзал..., с.146-152, 173-175, $176-184$.

10 М. Раев, Россия за рубежсом. История культуры русской эмиграиии, 1919-1939, Москва 1994. Полный список русских издательств и книжных магазинов в Берлине см.: Ibidem, c. 187-190. Подробнее о некоторых берлинских издательствах см.: Литературная энииклопедия Русского Зарубежья 1918-1940, т. 2: Периодика и литературные иентры, гл. ред. А. Н. Николюкин, Москва 2000 (по указателю содержания).

11 К. Шлёгель, Берлин, Восточный вокзал..., с. 184. 
денную Россию. Наконец, третья особенность - сосуществование и активное взаимодействие в пространстве русского Берлина эмигрантской и советской составляющих, поскольку в первые послевоенные годы между советской Россией и Германией сложились вполне дружественные отношения, в 1922 г. закрепленные Рапалльским советско-германским договором о восстановлении дипломатических отношений, что позволяло развивать торговые связи и культурный обмен; после заключения договора в Берлине появились советское посольство и торгпредство ${ }^{12}$. Германия на некоторое время стала единственной открытой для советских граждан страной, чем воспользовались как те, кто стремился вырваться из советской России и получал разрешение на выезд „для поправки здоровья” или „с культурными целями”, так и те корреспонденты советских периодических изданий, писатели, инженеры, торговые представители, политические и государственные деятели и пр., которые выезжали туда временно по командировке советского правительства. Впрочем, далеко не все из последних намеревались вернуться - оставшиеся советские специалисты положили начало феномену невозвращенчества.

Интенсивность советско-эмигрантских связей зафиксирована во многих мемуарных, дневниковых и эпистолярных текстах эмиграции; о ней же пишут исследователи русской эмиграции, отмечая плотность и разностороннюю насыщенность советско-эмигрантского диалога как основной признак уникальности русского Берлина:

Существенное отличие „русского Берлина” от, скажем, „русской Праги”, „русского Харбина" и других литературных столиц межвоенной эмиграции, состоит как раз в беспрецедентной интенсивности „диалога” метрополии и эмиграции внутри данного острова русской культуры. „Диалог” этот выразился в различных формах неожиданного симбиоза противостоящих друг другу литературных и общественных сил, в лихорадочной их перегруппировке, калейдоскопической пестроте культурных антреприз, но более всего - в характере деятельности причастных к „берлинскому периоду” литераторов ${ }^{13}$.

12 Подробнее о жизни и деятельности советского посольства в Берлине см.: ibidem, c. $199-241$.

13 Л. Флейшман, Р. Хьюз, О. Раевская-Хьюз, Русский Берлин: 1921-1923, Париж-Москва 2003, с. 6; ср. мнение Глеба Струве: „...в отличие от парижан, пражан, белградцев, о некоторых проживающих в это время в Берлине русских писателях трудно было сказать, советские они или эмигрантские", Г. П. Струве, Русская литература в изгнании, Париж-Москва 1996, с. 34; Нина Берберова рассматривает русский Берлин как пространство переплетения, расплавления друг в друге, переливания одного в другое прошлого и настоящего - к первому относятся „губернаторша и генерал, клянущие революцию, и поэт Минский, младший современник Надсона, приветствующий ее; едва унесшие ноги от революции “старые эмигранты”, то есть социалисты царского времени, вернувшиеся к себе в Европу после того, как часок побыли на родине; и пионер велосипеда и фотографии Вас. Ив. Немирович-Данченко [...] И Нина Петровская, [...] брюсовская Рената [...] И писательница Лаппо-Данилевская"; ко второму - Виктор Шкловский, Марк Слоним, Борис Пастернак, Владимир Лидин, Модест Гофман, Николай Оцуп, Виктор Ирецкий, либо имевшие статус советских писателей, либо

Slavica Wratislaviensia 172, 2020

(C) for this edition by CNS 
В результате Берлин на несколько лет сделался пространством вынужденного, но при этом относительно мирного сосуществования двух „Россий в миниатюре": ушедшей в прошлое императорской и возникшей на ее обломках советской ${ }^{14}$.

Разумеется, в эти же годы складывались и другие европейские и не только центры рассеяния, однако они осознавались еще не в рамках оппозиции „столица-провинция”, а в зависимости от своей специфики: Прага - как „русский Оксфорд”, Белград - как центр русской армии в изгнании, столицы Польши, Финляндии и балтийских государств, до 1917 г. входивших в состав Российской империи, - как лимитрофы, где родившимся на этих территориях было возможно оптировать новое гражданство. Кроме того, в 1920-1921 гг. были заключены советско-латвийский, советско-финский и советско-польский мирные договоры.

В силу того, что все эмигранты в эти годы воспринимали свое положение как временное, а центры рассеяния, в которых оказались, - как промежуточные, противостояние собственно эмигрантских столицы и провинции еще не сформировалось, а истинными столицами в сознании эмиграции оставались Петербург и Москва в их исторически сложившемся противостоянии.

\section{Часть 2. Берлин - Париж - Нью-Йорк}

Стабилизация немецкой марки осенью 1923 г. в результате проведенной правительством Веймарской республики реформы резко ухудшила финансовое положение эмигрантов и привела к началу их массового исхода из Берлина. Сокращению русского населения города способствовало и то, что к началу 1924 г. на родину были отправлены последние российские военнопленные. Однако самый значительный удар по русскому Берлину нанес прорыв Советской Россией дипломатической блокады: 7 февраля 1924 г. были установлены дипломатические отношения с Италией, 8 августа - с Великобританией, 28 октября - с Францией. Промежуточный период „сидения на чемоданах” завершился, и пришло понимание того, что „большевики - это надолго", следовательно, необходимо переходить на оседлое положение.

Путей исхода из Берлина было два: назад в Россию или дальше в Европу; конечным пунктом второго большинство эмигрантов осознавало Париж, к 1925 году обретший статус эмигрантской столицы и сохранявший его на протяжении пятнадцати лет, до поражения Франции и оккупации Парижа в 1940 г. В эти годы окончательно сложилась эмигрантская география и выстроилась внутриэмигрантская статусная иерархия: зарубежная Россия сделалась раскинувшимся по всему миру государством „поверх и вне границ”

считавшиеся просоветскими, либо через некоторое время вернувшиеся в Советскую Россию (Н. Н. Берберова, Курсив мой. Автобиография, Москва 1996, с. 186-187).

$14 \mathrm{Cp}$. основанное на мнении Ильи Эренбурга мнение Шлёгеля: „Это было место, где произошло смешение «чистых и нечистых»”, К. Шлёгель, Берлин, Восточный вокзал..., с. 194. 
со столицей в Париже; все остальные центры рассеяния получили статус провинциальных. Переезд в Париж, среди прочего, означал бесповоротный отрыв от России и переход к статусу эмигранта - своего рода экзистенциальный выбор, „скачок в никуда”. Поэтому путь многих русских берлинцев во французскую столицу был не прямым, а окольным: через Италию, Чехию и другие центры диаспоры ${ }^{15}$.

В результате берлинской, и не только берлинской, „прививки” к уже существовавшей парижской ветви диаспоры в Париже сложился уникальный русский анклав: административный, политический, общественный, культурный, научный ${ }^{16}$. Сюда переехали многие берлинские газеты и издательства, здесь было сосредоточено большинство эмигрантских организаций, союзов, объединений, землячеств, благотворительных фондов; здесь работал Земгор (Земско-городской союз), поддерживавший детские и образовательные учреждения. В Париже обосновался глава Русской зарубежной церкви митрополит Евлогий — и здесь же был штаб созданного ген. Петром Врангелем в 1924 г. Русского общевоинского союза (РОВСа). В Париже выходили две ведущие газеты эмиграции: „Последние новости” и „Возрождение” и главный эмигрантский общественно-политический и литературный журнал „Современные записки", название которого в режиме двойной аллюзии отсылало к классике отечественной журналистики предыдущего века: „Современнику” и „Отечественным запискам”. О богатстве, разнообразии и плотности русской жизни в Париже в межвоенные десятилетия дает исчерпывающее представление ее четырехтомная хроника, основанная на материалах периодической печати и других документах эмиграции ${ }^{17}$. Именно в Париже к концу 1930-х гг. зародилась мысль о создании „Золотой книги эмиграции” как памятнике „исторической единственности” этого явления ${ }^{18}$; здесь же планировалось создать музей русского зарубежья.

В Париже разворачивались значимые для всей диаспоры общественнополитические, литературные, научные полемики: о путях развития России,

15 См., напр., воспоминания Нины Берберовой: „Мы не остались в Берлине, где жить нам было нечем, мы не поехали в Италию, как Зайцевы [...], и мы не поехали в Париж, как Ремизовы, потому что мы боялись Парижа, да, мы оба боялись Парижа, боялись эмиграции, боялись безвозвратности, окончательности нашей судьбы и бесповоротного решения остаться в эмиграции”, Н. Н. Берберова, Курсив мой.., с. 243.

16 К середине 1920-х гг. во Франции проживала одна треть русских эмигрантов, рассредоточившихся после исхода из России в двадцати пяти странах нескольких континентов; бо́льшая часть французской ветви диаспоры была сосредоточена в Париже; см. Русский Париж, сост., предисл. и коммент. Т. П. Буслаковой, Москва 1998, с. 6.

17 Русское Зарубежье: Хроника научной, культурной и общественной жизни: Франиия, под общей ред. Л. А. Мнухина, т. 1-4, Париж-Москва 1995-1997.

18 Г. Адамович, Вклад русской эмиграции в мировую культуру, б. и., Париж 1961, с. 6; война и оккупация Франции помешали реализации этих замыслов, однако „Золотую книгу” через несколько десятилетий удалось издать, см.: Русское зарубежье. Золотая книга эмиграиии. Первая треть ХХ века. Энииклопедический биографический словарь, под общ. ред. В. В. Шелохаева, Москва 1997.

Slavica Wratislaviensia 172, 2020

(C) for this edition by CNS 
о судьбе и миссии эмиграции, об эмигрантской и советской литературе, о литературе в эмиграции, о судьбе молодого эмигрантского поколения и пр. ${ }^{19}$ За этими полемиками следила, откликалась на них и в некоторых случаях принимала в них участие и эмигрантская провинция (см., напр., участие пражанина Альфреда Бема в полемике парижан Георгия Адамовича и Владислава Ходасевича, „войну” берлинца Владимира Набокова и парижского литературно-художественного журнала „Числа" ${ }^{20}$ ).

Париж сделался эталоном, на который в режимах принятия или отторжения равнялись русские Берлин, Прага, Белград, Варшава, Рига, Таллин, Харбин, Нью-Йорк и др. Материалы парижских газет перепечатывали (не всегда законным путем, нередко без ведома авторов и без гонорара) газеты всех перечисленных и многих других центров рассеяния; провинциальные авторы стремились опубликовать свои работы в парижских изданиях, стать полными или ассоциированными членами парижских союзов и объединений. В свою очередь, и парижане не пренебрегали провинцией: публиковались в провинциальных изданиях и издательствах; посещали провинциальные центры с гастролями, концертами и лекциями; как почетные гости участвовали в различных культурных событиях провинции, хотя нередко делали это исключительно ради почета и заработка, а о провинциалах отзывались весьма снисходительно ${ }^{21}$. Иными словами, отношения эмигрантской столицы и провинции складывались в режиме диалога-противостояния: ощущая себя частями единого целого - зарубежной России, — обе стороны стремились к сотрудничеству, не забывая при этом о сложившейся внутри-эмигрантской иерархии. И даже стремление провинции нарушить установившийся иерархический порядок не отрицало самого факта его существования.

Непродолжительная „странная война”, завершившаяся молниеносным наступлением немецкой армии в мае-июне 1940 г. и оккупацией французской столицы, привела к массовому исходу населения из города. Для русских парижан, как и в случае с исходом из Берлина, существовали два пути: бегство на юг Франции, в т. наз. свободную зону, и эмиграция за океан ${ }^{22}$.

19 Подробнее см.: М. А. Омельченко, В поисках России: общественно-политическая мысль русского зарубежья о револючии 1917 г., большевизме и будущих судьбах российской государственности (историко-политический анализ), Санкт-Петербург 1996; О. Р. Демидова, Метаморфозы в изгнании: Литературный быт русского зарубежья, Санкт-Петербург 2003, с. 135-197; Ю. А. Азаров, Диалог поверх барьеров..., с. 28-115.

20 Подробнее с исчерпывающей литературой вопроса см.: О. Р. Демидова, Метаморфозы в изгнании..., с. $172-197$.

21 Подробный философско-эстетический анализ с многочисленными примерами из эмигрантской периодики и мемуаристики см. Ibidem, с. 32-36.

22 Подробнее о русском исходе из Парижа см.: О. Р. Демидова, После Парижа: письма в Англию (из архива Б. И. Элькина), „Russian Studies. Ежегодник русской филологии и культуры” 2001, т. 3, № 4, с. 184-200; , Мь можем быть только летописиами ... ”. Письма М. Осоргина А. Полякову. 1940-1942, публ., вступит. ст. и коммент. О. Демидовой, [в:] Диаспора: Новые материаль, вып. 1, отв. ред. В. Аллой, Париж-Санкт-Петербург 2001, с. 422-476; 
Сложившиеся исторические обстоятельства привели к концу „блистательного русского Парижа" и к очередной смене эмигрантской столицы - на этот раз она „переехала” в Нью-Йорк, где была сделана попытка возродить прежнюю жизнь на новом месте.

Впрочем, корректнее было бы говорить о необходимости вписать и/или встроить русский Париж в русский Нью-Йорк, имевший давнюю историю 23 , сложившуюся русскую диаспору, определенные традиции и инфраструктуру: в Нью-Йорке издавалась самая старая русскоязычная газета „Новое русское слово”, были свои издательства, журналы, общественно-политические и литературные объединения, благотворительные организации и фонды и своя русская жизнь с ее устоявшейся внутренней иерархией ${ }^{24}$. Вполне устоявшимся было и отношение русских парижан к русскому Нью-Йорку как к глубокой эмигрантской провинции. И хотя в Нью-Йорке в 1942 г. Марком Алдановым и Михаилом Цетлиным был создан „Новый журнал” как преемник парижских „Современных записок”, Софией Прегель - „Новоселье”, группой эсеров — „За свободу” (1941), воссозданы некоторые парижские периодические издания, преимущественно общественно-политической и узко-партийной ориентации (напр., эсеровский „Социалистический вестник”), а в 1952 г. при финансовой поддержке „Фонда Форда” основано русскоязычное „Издательство имени Чехова”, для большинства бывших парижан Америка не стала новой родиной, оставшись лишь безопасной и удобной для жизни страной. При этом формально имевший статус новой эмигрантской столицы Нью-Йорк по богатству, разнообразию и глубине интеллектуальной и культурной жизни не шел ни в какое сравнение с оставленным Парижем ${ }^{25}$.

Кроме непреодолимого европоцентризма парижан и привычного восприятия Нью-Йорка как эмигрантской провинции, существенную роль в этом сыграло и то, что в Нью-Йорке в военные и послевоенные годы сосуществовали две принципиально различные эмиграции: „старая”, т. е. первая, пореволюционная, и „новая”, получившая название второй волны и состоявшая из т. наз. перемещенных лиц - бывших советских граждан, которым оказывали явное предпочтение американские власти (например, издательство имени Чехова было создано преимущественно для поддержки литераторов второй волны). В известном смысле можно говорить о повторении берлинской ситуации на-

Н. П. Вакар, Дневник (1938-1940), публ., вступ. ст. и коммент. О. Р. Демидовой, [в:] Минувшее: Исторический альманах, Санкт-Петербург, 1998, № 24, с. 621-627 (записи от 9, 10, 11 июня 1940 г.).

23 Об истории русской эмиграции в Америку см. О. Р. Демидова, Эмиграция из России в США в ХХ веке: история и типология, [в:] О. Р. Демидова, Изгнанье как посланье: эстезис и этос русской эмигращии, Санкт-Петербург 2015, с. 127-135.

24 Подробнее см.: Ю. А. Азаров, Диалог поверх барьеров..., с. 240-265.

25 Подробнее см.: О. Р. Демидова, Русско-еврейский Париж в русско-еврейском НьюЙорке: рождение новой столицы эмиграции, [в:] Русское еврейство в зарубежье, т. 18: Русские евреи в Америке, кн. 3, ред. Э. Зальцберг, М. Пархомовский, Иерусалим-Торонто-СанктПетербург 2009, с. 24-33. 
чала 1920-х гг. — с той лишь разницей, что, в отличие от Берлина, советская и эмигрантская часть которого различались прежде всего по идеологическим и политическим основаниям, в Нью-Йорке встретились представители двух радикально отличных друг от друга типов культуры, которых ничто или мало что объединяло. О принципиальном и потому непреодолимом различии двух волн пишет Нина Берберова, сопоставляя прежний парижский и новый нью-йоркский салоны известной меценатки Марии Цетлиной:

Они [гости - О. Д.] теперь не столько сходились, сколько отличались друг от друга весьма существенно. И разделялись по совершенно другим линиям, чем это когда-то было в Париже. Там прежде всего был раздел поколений, затем был раздел политическим. [...] Там можно было почувствовать москвича и петербуржца или бывшего столичного жителя и провинциала, человека, прошедшего гражданскую войну, и человека, прошедшего университет. Здесь эти категории не существовали ${ }^{26}$.

Самым существенным типологическим свойством новых эмигрантов Берберова считает „пензенскую психологию”, жизнь по принципу „у нас в Пензе лучше" - т. е. тот глубокий провинциализм, который был присущ как „новым” эмигрантам, так и американской ветви диаспоры в целом, и который обеспечил представителям второй волны успех в Новом Свете 27 .

Резюмируя, можно утверждать, что в условиях эмиграции действительный и/или приписываемый столичный и, соответственно, провинциальный статус определялись тремя основными критериями: антропологическим, аксиологическим, культурно-типологическим, действовавшими в режиме притяжения - отталкивания с опорой на обстоятельства сугубо экзистенциального порядка, на т. наз. „человеческий фактор” и на ориентацию на определенный тип культуры и соответствующую ему культурную традицию.

\section{Библиография}

Adamovič G. V., Vklad russkoj émigracii v mirovuû kul'turu, b.i., Pariž 1961.

Azarov Ŭ. A., Dialog poverh bar'erov. Literaturnaja žizn' russkogo zarubež'â: centry emigracii, periodičeskie izdaniâ, vzaimosvâzi (1918-1940), Sovpadenie-Moskva 2005.

Berberova N. N., Kursiv moj. Avtobiografiâ, Soglasie, Moskva 1996.

Demidova O. R., Izgnanje kak poslanje: estezis i etos russkoi emigracii, Russkaja kul'tura, SanktPeterburg 2015.

Demidova O. R., Metamorfozy v izgnanii: literaturnyj byt russkogo zarubež'â, Giperion, SanktPeterburg 2001.

Demidova O. R., Posle Pariža: pis'ma v Angliû (iz arhiva B. I. Ėl'kina), „Russian Studies. Ežegodnik russkoj filologiii kul'tury” 2001, t. 3, № 4.

Demidova O. R., Russko-evrejskij Pariž v russko-evrejskom Njû-Jorke: roždenie novoi stolicy, [v:] Russkoe evrejstvo v zarubežje, t. 18, Russkie evrei v Amerike, kniga 3, red. È. Zal'cberg, M. Parhomovskij, Giperion, Ierusalim-Toronto-Sankt-Peterburg 2009.

26 Н. Н. Берберова, Курсив мой..., с. 575.

27 Подробнее см.: О. Р. Демидова, Американский опыт Нины Берберовой, [в:] О. Р. Демидова, Изгнанье как посланье..., с. 136-148.

Slavica Wratislaviensia 172, 2020

(C) for this edition by CNS 
Flejšman L., Hjûz R., Raevskaja-Hjûz O., Russkij Berlin 1921-1923, YMCA-Press, Russkij put', Pariž-Moskva 2003.

Gerhardi U., Poligloty, Kabinetnyj učënyi, Ekaterinburg-Moskva 2017.

Lejkind O. L., Mahrov K. V., Severûhin D. Â., Hudožniki Russkogo Zarubež'â 1917-1939. Biografičeskij slovar', „Notabene”, Sankt-Peterburg 1999.

Literaturnaâ enciklopediâ russkogo zarubežjâ 1918-1940, t. 2.: Periodika i literaturnye centry, gl. red. A. N. Nikolûkin, ROSSPÉN, Moskva 2000.

„My možem byt' tol'ko letopiscami...”. Pis'ma Mihaila Osorgina A. Polâkovu. 1940-1942, publ., vstup. st. i comment. O. R. Demidovoi, [v:] Diaspora: Novye materialy, vyp. 1, otv. red. V. Alloj, Atheneaum, Feniks, Pariž-Sankt-Peterburg 2002.

Omel'čenko N. A., V poiskah Rossii: obŝestvenno-političeskaâ mysl' russkogo zarubežjâ o revolûcii 1917 g., bol'ševizme $i$ budusìh sud'bah rossijskoj gosudarstvennosti (istoriko-političeskij analiz), Izdatel'stvo PHGI, Sankt-Peterburg 1996.

Posle Pariža: pis'ma v Angliû (iz arhiva B. I. Él'kina), publ., vstup. st. i comment. O. R. Demidovoi, „Russian Studies. Ežekvartal'nik russkoi filologii i kultury”, 2001, t. 3, № 4.

Raev M., Rossiâ za rubežom. Istoriâ kul'tury russkoj émigracii, 1919-1939, Progress-Akademiâ, Moskva 1994.

Russkaâ provinciâ: mif - tekst - real'nost', sost. A. F. Belousov i T. V. Civjân, Tema, MoskvaSankt-Peterburg 2000.

Russkij Pariž, sost., predisl i komment. T. G. Buslakovoj, Izdatel'stvo MGU, Moskva 1998.

Russkoe zarubežje: Hronika naučnoi, kul'turnoi i obŝestvennoi žizni: Franciâ, t. 1-4, pod obŝej red. L. A. Mnuhina, YMCA-Press, ÉKSMO, Pariž-Moskva 1995-1997.

Russkoe zarubežje. Zolotâ̂ kniga emogracii. Pervaâ tret' XX veka, pod obŝ. red. V. V. Šelohaeva, ROSSPÉN, Moskva 1997.

Soročan A. U.., Stroganov M.V., Provincial'nyi tekst v russkoi hudožestvennoj kul'ture, „Russian Studies. Ežekvartal'nil russkoj filologii i kul'tury” 2000, t. 3, № 2.

Struve G. P., Russkaâ literatura v izgnanii, YMCA-Press, Russkij put', Pariž-Moskva 1996.

Šlëgel' K., Berlin, Vostočnyj vokzal. Russkaâ emigraciâ v Germanii meždu dvumâ voinami, Novoe literaturnoe obozrenie, Moskva 2004.

Vakar N. P., Dnevnik (1938-1940), publ., vstup. st. i comment. O. R. Demidovoi, [v:] Minuvšee: Istoričeskij al'manah, Athenaeum-Feniks, Sankt-Peterburg 1998, № 24.

\section{The capital and provinces: The émigré version}

\section{Summary}

The article presents the cultural dichotomy "the capital — the provinces" in a diachronic perspective, the author reconstructing its history and typology to apply the theoretical basis to the analysis of this phenomenon in Russian first-wave émigré culture. Presenting a minute retrospective analysis of the history of the three émigré capitals succeeding each other in the 1920s-1940s (Russian Berlin - Russian Paris - Russian New York), the author argues that the corresponding status (the capital — the provincial) in the diaspora relied on three major criteria: the anthropological, the axiological, and the culturally typological, which, in their turn, were actualized by existential circumstances, the so-called human factor, and the orientation toward a certain type of culture and cultural tradition.

Keywords: capital, the provinces, culture, opposition, dichotomy, Russian emigration

Slavica Wratislaviensia 172, 2020

(C) for this edition by CNS 


\section{Stolica i prowincja — wariant emigracyjny}

\section{Streszczenie}

Artykuł zawiera analizę diachroniczną dychotomii kulturowej „stolica-prowincja”, historię jej kształtowania oraz typologię. Elementy te tworzą podstawę teoretyczną omówienia tego zjawiska w historii kultury pierwszej fali emigracji rosyjskiej. Na podstawie szczegółowej analizy historii trzech kolejnych stolic emigracyjnych z lat 1920-1940 (rosyjskiego Berlina — rosyjskiego Paryża - rosyjskiego Nowego Jorku) autorka dochodzi do wniosku, że status stołeczności-prowincjonalności wyznaczany był przez trzy główne kryteria: antropologiczne, aksjologiczne i kulturowo-typologiczne, aktualizowane przez warunki egzystencjalne, tak zwany czynnik ludzki oraz orientację na określony typ kultury i określoną tradycję kulturową.

Stowa kluczowe: stolica, prowincja, kultura, opozycja, dychotomia, emigracja rosyjska 